\title{
Observations on experimental colonisation of mice by ureaplasmas of human origin
}

\author{
D. TAYLOR-ROBINSON and P. M. FURR
}

Division of Medicine, Imperial College of Science, Technology and Medicine, St Mary's Hospital, Paddington, London W2 $1 \mathrm{NY}$

\begin{abstract}
Three serovars $(5,8$ and 10$)$ of Ureaplasma urealyticum were inoculated intravaginally into groups of oestradiol-treated young adult BALB/c strain mice. Hormone treatment was essential for vaginal colonisation. The proportion of mice colonised initially and the persistence of colonisation were different with the three serovars; half of those given serovar 8 were still colonised after 84 days. A strain of serovar 5 after a further 50 subcultures in vitro was a little less persistent than it was before such subculture, but not in a way to suggest that subculturing was the main reason for differences in the behaviour of the serovars. At autopsy of six mice that were still colonised vaginally 158 days after inoculation of serovar 8 , spread to the upper genital tract was shown to have occurred in three of them and dissemination to the liver and kidney in one. Compared with immunocompetent mice of strain CB20, such dissemination was not a feature in genetically related mice with severe combined immunodeficiency. This is not in keeping with the situation in hypogammaglobulinaemic patients in whom ureaplasmas and other mycoplasmas are known to disseminate. However, differences in the proportion of immunocompetent mice colonised or in ureaplasmal persistence with different serovars may act as a marker for differences in human pathogenicity and is worthy of further study.
\end{abstract}

\section{Introduction}

Ureaplasma urealyticum bacteria are of human origin and are one of six species within the genus Ureaplasma in the family Mycoplasmataceae, class Mollicutes [1]. As the name suggests, members of the genus Ureaplasma metabolise urea and are unique among the class in their ability to do so [1]. Trivially, they have been termed ureaplasmas. Those of human origin have been associated with several genital tract, reproductive, neonatal and arthritic diseases, although their status as a cause of some of these has been and continues to be debated [2].

The development of an animal model as a means of assessing the pathogenicity of ureaplasmas and their status as a cause of disease would be helpful. A

Received 26 March 2002; revised version received 11 June 2002; accepted 13 June 2002.

Corresponding author: Professor D. Taylor-Robinson (e-mail: dtr@vache99.freeserve.co.uk). previous study showed that prior administration of oestradiol rendered female mice susceptible to genital tract colonisation with serovar 8 of $U$. urealyticum, hormone-untreated mice being resistant [3]. Of three strains of mice, TO, CBA and BALB/c, the latter strain was the most susceptible. Ureaplasmas were recovered from vaginal swabs for 21-163 days and occasionally there was spread to the uterine horns and ovaries. Genital tract colonisation did not protect mice against recolonisation by the same ureaplasmal serovar. Subsequently, the survival of different serovars, the effect of multiple passage in vitro on the ability of a strain to colonise, dissemination of organisms and colonisation in immunodeficient mice have been examined in greater detail. These studies comprise this communication.

\section{Materials and methods}

Mice

Young (8-10 week-old) adult female mice of strain $\mathrm{BALB} / \mathrm{c}$ were used. However, in one experiment, strain CB20 and a strain closely related genetically but with 
severe combined immunodeficiency (SCID) were used. Groups of 10 mice were used for each of the ureaplasmal serovars and strains tested, except where indicated.

\section{Hormone treatment}

Oestradiol benzoate (Paines and Byrne, Greenford, Middlesex) was given subcutaneously. A dose of 0.5 $\mathrm{mg}$ in a $0.1-\mathrm{ml}$ volume was administered on four occasions, at weekly intervals. All mice were hormone treated unless stated otherwise.

\section{Medium}

The liquid medium used to grow ureaplasmas for mouse inoculation and to isolate them subsequently has been described in detail previously [4]. Briefly, it comprised beef heart infusion supplemented with horse serum $20 \%$, yeast extract $10 \%$, urea $0.1 \%$, penicillin 1000 i.u. $/ \mathrm{ml}$ and phenol red $0.002 \%$.

\section{Inocula and inoculation procedure}

The $U$. urealyticum serovars and strains used were as follows: serovar 5 (strain 43a) was isolated originally in this laboratory [5] and was used after nine subcultures in medium, the minimum required for cloning three times; the same strain was also used after 50 more subcultures in medium. Serovar 8 was obtained originally from F. T. Black (Aarhus, Denmark) and was subcultured eight times after receipt in the laboratory (prior number of subcultures unknown). Serovar 10 of unknown but multiple subcultures was obtained from J. A. Robertson (Edmonton, Alberta, Canada). These serovars may now be obtained from the American Type Culture Collection. A strain of $U$. urealyticum freshly isolated in this laboratory from a joint aspirate from a hypogammaglobulinaemic patient was not serotyped. The number of organisms of each strain, measured in terms of colour-changing units $(\mathrm{ccu}) / \mathrm{ml}$, in each inoculum is given in the text below. An inoculum volume of $50 \mu \mathrm{l}$ was introduced into the vagina of each mouse with an Eppendorf pipette, without anaesthesia. This was accomplished at the same time as the mouse received the second dose of oestradiol.

\section{Vaginal cytology}

A nasopharyngeal swab (Medical Wire and Equipment, Corsham, Wiltshire) was inserted into the mouse vagina, rotated and then rolled along a $3^{\prime \prime} \times 1$ " glass slide. The smear was fixed for $30 \mathrm{~min}$ in methanol and stained with Giemsa. The phase of the reproductive cycle was determined by assessing the presence or absence of leucocytes and nucleated and cornified squamous epithelial cells, an abundance of the latter being characteristic of the oestrous phase of the cycle [6].

\section{Isolation of ureaplasmas}

Mice were examined at weekly intervals after inoculation of the ureaplasmas, except where indicated in the Tables. A nasopharyngeal swab, as above, was inserted into the vagina and the swab contents were then expressed in $1.8 \mathrm{ml}$ of medium contained in a $2.5-\mathrm{ml}$ screw-capped vial; this was regarded as a 1 in 10 dilution. Further 10-fold dilutions were made up to a dilution of 1 in $10^{8}$. At autopsy, the spleen, liver, kidneys and lungs were removed and portions were homogenised in mycoplasmal medium to produce $10 \%$ $\mathrm{w} / \mathrm{v}$ suspensions which were then diluted serially as above. Multiplication of ureaplasmas was denoted by a change in colour of the medium from yellow to red on incubation at $37^{\circ} \mathrm{C}$. When colour changes no longer occurred, the highest dilution at which a change was seen was deemed to contain $1 \mathrm{ccu}$; this is equivalent to c. $1 \mathrm{cfu}$ (unpublished data). Swabs from mice inoculated intravaginally with medium not containing ureaplasmas did not cause a colour change.

\section{Results}

Colonisation of the vagina of BALB/c mice by different serovars of $U$. urealyticum

The results of inoculating groups of $10 \mathrm{BALB} / \mathrm{c}$ mice with serovar $8\left(2.5 \times 10^{5} \mathrm{ccu}\right)$, serovar $10\left(2.5 \times 10^{4}\right.$ ccu) or serovar $5\left(2.5 \times 10^{4} \mathrm{ccu}\right)$ are shown in Table 1 . All mice inoculated with serovar 8 were colonised and half of them remained so after 84 days. Only four of 10 mice were colonised initially by serovar 10 , and only two of these remained so after 21 days, a number significantly smaller than for serovar $8(\mathrm{p}=0.007$, Fisher's exact test); thereafter, colonisation did not persist. Seven of 10 mice were colonised initially by the early in-vitro pass of serovar 5. Although the numbers of organisms recovered from these colonised mice were as large as from mice given serovar 8 , the proportion of infected mice declined more rapidly than for serovar 8 , only one of the mice given early-pass serovar 5 being colonised after 84 days. None of the serovars was able to colonise hormone-untreated mice.

\section{Effect of multiple in-vitro subculture of ureaplasmas on mouse colonisation}

Serovar 5 , after a further 50 subcultures in vitro, was inoculated at a dose of $2.5 \times 10^{4} \mathrm{ccu}$ in $10 \mathrm{BALB} / \mathrm{c}$ mice. The results are shown in Table 1 . Initially, the number of mice colonised (seven) was the same as for mice given the early in-vitro pass of serovar 5 . Colonisation persisted for at least 56 days in both groups. Although the proportion of mice colonised by multiply subcultured organisms diminished a little more rapidly than the proportion colonised by organisms subcultured only a few times, the difference was not statistically significant ( $\mathrm{p}>0.1$, Yates' correction). 
Table 1. Vaginal colonisation of $\mathrm{BALB} / \mathrm{c}$ mice by different serovars of $U$. urealyticum

\begin{tabular}{|c|c|c|c|c|c|c|}
\hline \multirow[b]{2}{*}{ Ureaplasma } & \multicolumn{6}{|c|}{$\begin{array}{c}\text { Number of mice colonised and titre range }\left(\log _{10} \mathrm{ccu} / \mathrm{ml}\right) \text { per group of } 10 \\
\text { on indicated day after inoculation }\end{array}$} \\
\hline & 7 & 21 & 35 & 42 & 56 & 84 \\
\hline Serovar 8 & $\begin{array}{l}10 \\
3-6\end{array}$ & $\begin{array}{l}10 \\
4-6\end{array}$ & $\begin{array}{c}8 \\
1-6\end{array}$ & $\begin{array}{c}8 \\
4-5\end{array}$ & $\begin{array}{c}6 \\
3-5\end{array}$ & $\stackrel{5}{4-6}$ \\
\hline Serovar 10 & $\begin{array}{c}4 \\
4-7\end{array}$ & 2 & $-^{*}$ & $\ldots$ & $\ldots$ & $\ldots$ \\
\hline Serovar 5 & $\begin{array}{c}7 \\
2-7\end{array}$ & $\begin{array}{c}6 \\
4-6\end{array}$ & $\begin{array}{c}5 \\
3-6\end{array}$ & $\stackrel{4}{5-6}$ & $\stackrel{3}{4-6}$ & $\begin{array}{l}1 \\
6\end{array}$ \\
\hline $\begin{array}{l}\text { Serovar } 5 \\
\text { passed }^{\dagger}\end{array}$ & $\begin{array}{c}7 \\
2-7\end{array}$ & $\begin{array}{c}6 \\
3-6\end{array}$ & $\begin{array}{l}2 \\
6\end{array}$ & $\begin{array}{l}2 \\
6\end{array}$ & $\begin{array}{c}2 \\
4-6\end{array}$ & 0 \\
\hline
\end{tabular}

*Experiment then terminated.

${ }^{\dagger}$ After a further 50 subcultures in vitro.

\section{In-vivo dissemination of ureaplasmas}

Of $10 \mathrm{BALB} / \mathrm{c}$ mice colonised originally with serovar 8,6 were still colonised 158 days later, at which time they were autopsied. The results of the autopsy examination are shown in Table 2. In three of the six mice, the ureaplasmas had spread to the uterus and in one of these three mice to the right ovary. They were also recovered from the liver and kidney of one mouse.

\section{Susceptibility of SCID mice and their immunocompetent counterparts to ureaplasmas}

Two groups of five mice, one of strain CB20 and the other closely related genetically but with SCID, were inoculated with $2.5 \times 10^{5} \mathrm{ccu}$ of a ureaplasmal strain freshly isolated from the knee of a hypogammaglobulinaemic patient with septic arthritis. A further two groups of mice of the same strains, but not receiving hormone treatment, were also inoculated with the ureaplasmal strain. The results are shown in Table 3. None of the untreated mice became colonised, whereas all oestradiol-treated mice in both the CB20 and SCID groups did so. However, there was no evidence that colonisation persisted longer in the SCID strain of mice than in the CB20 strain. At day 21 after inoculation, one mouse from each of the groups was killed and an autopsy was performed. Ureaplasmas were isolated from the right and left uterine horns and ovaries of both animals but there was no evidence of dissemination to the spleen, liver or kidneys. At day 36, the remaining three CB20 mice and two SCID mice were killed. Two of the CB20 mice were still colonised in the vagina and the ureaplasmas were recovered from
Table 3. Vaginal colonisation of immunocompetent and immunodeficient (SCID) mice by a strain of $U$. urealyticum

\begin{tabular}{lccccc}
\hline & & \multicolumn{2}{c}{$\begin{array}{c}\text { Number of } 5 \text { mice colonised and titre } \\
\text { range }\left(\log _{10} \mathrm{ccu} / \mathrm{ml}\right) \\
\text { after inoculation }\end{array}$} \\
\cline { 3 - 6 } $\begin{array}{l}\text { Mouse } \\
\text { strain }\end{array}$ & $\begin{array}{c}\text { Oestradiol } \\
\text { treatment }\end{array}$ & 7 & 14 & 21 & 36 \\
\hline CB20 & + & 5 & 5 & $4^{*}$ & $2^{\dagger}$ \\
& & $2-6$ & $1-6$ & $2-6$ & 6 \\
SCID & - & 0 & 0 & 0 & 0 \\
& + & 5 & $4^{*}$ & $3^{\dagger}$ & $0^{\dagger}$ \\
& & $2-5$ & $2-4$ & $2-4$ & 0 \\
\hline
\end{tabular}

Autopsy results are given in the text.

* Of four mice, one having died.

$\dagger$ Of three mice, one having died.

tof two mice, one having died.

the uterus and ovaries of each. However, neither of the SCID mice was ureaplasma-positive at any of these sites.

\section{Discussion}

It had been shown previously that, of several strains of female adult mice, the BALB/c strain was the most susceptible to vaginal colonisation by $U$. urealyticum [3]. This was the reason for using this strain to test several ureaplasmal serovars. An exact counterpart to the BALB/c strain but with severe immunodeficiency was not available; therefore, the CB20 strain that has a strain closely related genetically but with severe combined immunodeficiency was used. Irrespective of

Table 2. Spread of U. urealyticum serovar 8 from the vagina to other anatomical sites

\begin{tabular}{|c|c|c|c|c|c|c|c|c|}
\hline \multirow[b]{2}{*}{ Mouse no. } & \multirow[b]{2}{*}{ Vaginal titre* } & \multicolumn{7}{|c|}{ Presence $(+)$ or absence $(-)$ of ureaplasmas at indicated site } \\
\hline & & Throat & $\begin{array}{l}\text { Right uterine } \\
\text { horn }\end{array}$ & $\begin{array}{l}\text { Left uterine } \\
\text { horn }\end{array}$ & Right ovary & Spleen & Liver & Kidney \\
\hline 1 & 4 & - & + & - & - & - & - & - \\
\hline 2 & 5 & - & - & - & - & - & - & - \\
\hline 3 & 6 & - & + & - & - & - & - & - \\
\hline 4 & 6 & - & + & + & - & - & + & + \\
\hline 5 & 4 & - & - & - & - & - & - & - \\
\hline 6 & 6 & - & + & + & + & - & - & - \\
\hline
\end{tabular}

\footnotetext{
${ }^{*} \log _{10} \mathrm{ccu} / \mathrm{ml}$.
} 
the mouse strain, it had been shown before [3] that treatment of mice with oestradiol was essential for inducing susceptibility to ureaplasmas. This was confirmed here, the two strains of mice used (BALB/c and CB20) being insusceptible to colonisation by ureaplasmas unless treated with this hormone. Whether such induction is due to the hormone causing changes to the epithelium, or increasing the number of receptive epithelial cells, or both, is not known. Of course, the induction of host susceptibility does not account for the greater ability of some serovars to colonise. This must reside in the different propensities of micro-organisms comprising the serovars to attach to epithelial cells, as they have been shown to do in vitro [7], the lipoglycan in the ureaplasmal membrane [8] perhaps being important in the process.

It is interesting to note that the exact anatomical site of colonisation is also not known. Previous observations by electron microscopy of tissues from oestradioltreated mice inoculated with Mycoplasma hominis showed no attachment of the organisms to vaginal squamous epithelial cells but attachment to the cervical columnar epithelium [9]. Such a study has not been conducted with $U$. urealyticum, but surmising that the outcome might be similar would not seem unreasonable. Of course, taking specimens by vaginal swabbing does not enable differentiation to be made between the two anatomical sites. The swab may collect infected cervical cells that have sloughed into the vagina or an intra-vaginal swab may abrade cervical cells at collection. Thus, vaginal colonisation may be a misnomer. However, wherever initial colonisation occurs, it is interesting that it does so despite the enormous increase in the number of endogenous vaginal bacteria that is known to occur following oestradiol treatment, in which a situation is created not unlike bacterial vaginosis in women [10]. It is noteworthy that in women $M$. hominis and ureaplasmas are assumed to colonise the vaginal epithelium and the importance of the cervix has not been established. It would be of interest to determine whether removal of the cervical epithelium by hysterectomy diminishes or ablates 'vaginal' colonisation.

It was difficult to obtain precisely the same number of organisms in the inocula of the various serovars and strains tested in the mice. Nevertheless, there was evidence that the colonising ability of those tested was not the same and that, for some, persistence was longer than for others. This was a feature noted previously for different strains of M. hominis [11]. Multiple in-vitro subculture of a ureaplasmal strain resulted in only a slight, non-significant, decrease in the duration of mouse colonisation, suggesting that differences between serovars and strains in the way in which they behave in the mouse are more likely to be due to inherent differences between them rather than the number of in-vitro subcultures they have had. Spread of ureaplasmas to the upper genital tract (uterus and ovaries) was not uncommon, being seen in both BALB/c and CB20 strains of mice. On the other hand, haematogenous dissemination to other organs (spleen, liver, kidneys) was far less common.

Although the number of mice examined was small, it was apparent that ureaplasmas did not persist in the vagina of SCID mice in which the response of both $T$ and B cells is ablated. The reason for this is unclear but it seems remarkable in view of the fact that it had been shown previously that $M$. pulmonis organisms persisted in the vagina of BALB/c nude mice and could not be cleared by treating them with a tetracycline [12]. Furthermore, dissemination of ureaplasmas beyond the genital tract was not demonstrated in the SCID mice. Thus, such mice would not seem to mimic the human situation in which evidence that antibody is important in restraining mycoplasmas from disseminating haematogenously from a mucosal surface [13] is consistent with finding them often in the joints of hypogammaglobulinaemic patients with septic arthritis [14].

A vaginal polymorphonuclear leucocyte response to colonisation by ureaplasmas and, indeed, other mycoplasmas does not occur in the mice. This lack of response was also seen following colonisation of oestradiol-treated mice by gonococci [15] and may be due to the effect of the hormone. Nevertheless, differences in the proportion of mice colonised, or the duration of colonisation, or both, between different ureaplasmal serovars and strains may also reflect differences in their pathogenicity for the human host. This is a notion that is worth pursuing, particularly as biovar 2 strains of $U$. urealyticum have recently been associated with non-gonococcal urethritis in men [16].

\section{References}

1. Taylor-Robinson D, Tully JG. Mycoplasmas, ureaplasmas, spiroplasmas and related organisms. In: Collier L, Sussman M, Balows A (eds) Topley \& Wilson's microbiology and microbial infections, 9th edn, Vol 2, Systematic bacteriology (Balows A, Duerden BI; eds). London, Arnold. 1998: $799-827$.

2. Taylor-Robinson D, Furr PM. Update on sexually transmitted mycoplasmas. Lancet 1998; 351 Suppl 3: 12-15.

3. Furr PM, Taylor-Robinson D. The establishment and persistence of Ureaplasma urealyticum in oestradiol-treated female mice. J Med Microbiol 1989; 29: 111-114.

4. Taylor-Robinson D, Martin-Bourgon C, Watanabe T, Addey JP. Isolation of T-mycoplasmas from dogs and squirrel monkeys: biological and serological comparison with those isolated from man and cattle. J Gen Microbiol 1971; 68: 97-107.

5. Taylor-Robinson D, Csonka GW, Prentice MJ. Human intraurethral inoculation of ureaplasmas. $Q J$ Med 1977; 46: 309-326.

6. Rugh R. The mouse. Its reproduction and development. Minneapolis, Burgess Publishing. 1968: 38-39.

7. Manchee RJ, Taylor-Robinson D. Studies on the nature of receptors involved in attachment of tissue culture cells to mycoplasmas. Br J Exp Pathol 1969; 50: 66-75.

8. Smith PF. Mass cultivation of ureaplasmas and some applications. Pediatr Infect Dis 1986; 5(6 Suppl): S313-S315.

9. Furr PM, Sarathchandra P, Hetherington CM, Taylor-Robinson D. Site of localization of Mycoplasma pulmonis and Mycoplasma hominis in the genital tract of female mice demon- 
strated by culture and scanning and immuno-electron microscopy. Int J Exp Pathol 1995; 76: 131-143.

10. Furr PM, Taylor-Robinson D. The influence of hormones on the bacterial flora of the murine vagina and its implications for human disease. Microb Ecol Hlth Dis 1991; 4: 141-148.

11. Furr PM, Taylor-Robinson D. Oestradiol-induced infection of the genital tract of female mice by Mycoplasma hominis. J Gen Microbiol 1989; 135: 2743-2749.

12. Taylor-Robinson D, Furr PM. Observations on the antibiotic treatment of experimentally induced mycoplasmal infections in mice. J Antimicrob Chemother 2000; 45: 903-907.

13. Webster ADB, Furr PM, Hughes-Jones NC, Gorick BD, Taylor-
Robinson D. Critical dependence on antibody for defence against mycoplasmas. Clin Exp Immunol 1988; 71: 383-387.

14. Furr PM, Taylor-Robinson D, Webster ADB. Mycoplasmas and ureaplasmas in patients with hypogammaglobulinaemia and their role in arthritis: microbiological observations over twenty years. Ann Rheum Dis 1994; 53: 183-187.

15. Taylor-Robinson D, Furr PM, Hetherington CM. Neisseria gonorrhoeae colonises the genital tract of oestradiol-treated germ-free female mice. Microb Pathog 1990; 9: 369-374.

16. Povlsen K, Bjørnelius E, Lidbrink P, Lind I. Relationship of Ureaplasma urealyticum biovar 2 to nongonococcal urethritis. Eur J Clin Microbiol Infect Dis 2002; 21: 97-101. 